\title{
Influence of Political Parties in Political Stability in Pakistan: A Case Study of Hyderabad, Sindh, Pakistan
}

Hassan Bakhsh Noonari*

Syeda Aliya Fatima**

Dr. Muhammad Munir Ahmedani***

\begin{abstract}
The main purpose of this investigation is to analyze the participation of Political parties in the development of democratic culture in Pakistan. For this purpose survey was conducted among the students and the faculty members of political departments of various colleges of Hyderabad city. The data were collected through questionnaire using five point Likert scale and data were analyzed by using SPSS 22 version. The results of this study reveal that there is significant role of political parties for the development of democracy and also stability of economical conditions of the country. Most of the respondents are persuaded that the responsibility of political parties in political development of Pakistan is crucial but not admiring yet. They are of the view that political parties have not even played adequate role in direction of the political, social and economic growth of a country. Results of survey also demonstrate that the political setup of Pakistan desires considerable transformations, capacity building and institutionalization. It is concluded that the imperative role of democratic parties is to enhance the volume of political development in the interest of nation of Pakistan.
\end{abstract}

Keywords: Role of political parties, Political development, Political setup, Social and Economic Growth, Pakistan

\section{INTRODUCTION}

Political parties are the utmost imperative element of the political system in determining the route, nature and degree of political development. The desires and goals of political improvement can't be accomplished without political events (Akhtar, 2011). They may be basically organization of society, at the same time as army and forms are establishments of the country. Inside the developing nations, like Pakistan, few nation establishments are sturdy sufficient to counter the influence of society and its consultant governments (Hussain \& Kokab, 2013).

According to Weiner (1962), political system of any country depends on the fact that is controlling and allocating the resources. In countries with empowered democratic institutions, political forces take control of resources and lead the country towards political development. The political history of Pakistan clearly indicates the dominance of state institutions over political parties. Since getting independence in 1947, Pakistan has witnessed three different martial law periods from 1958 to 1971, 1977 to 1988 and 1999 to 2007. Even, military dictators nurtured few political parties to gain political support and manipulated them to prolong their dictatorships (Cohen, 2004).

The term 'political development' was used in 1960s to explain the process of 'political modernization' of newly emerging independent states after decolonization. The conception of political development implies that there is 'underdevelopment' and 'development. The

\footnotetext{
* Lecturer in Political Science, Government S.S.Arts \& Comerce College, Hyderabad.

${ }^{* *}$ PhD Scholar, Department of Education, Greenwich University, Karachi.

${ }^{* * *}$ Associate Professor of Commerce Government Boys Degree College Kohsar, Latifabad, Hyderabad.

$=$ International Research Journal of Education and Innovation 
underdevelopment of societies indicates that both human and material resources are not utilized properly to fulfil the needs of that society. Due to this, poverty and joblessness become widespread and people lead depressed lives (Rudebeck, 1970).

Ideological groups are frequently clarified as organized middle people between basic culture and the people who pick and execute decisions like parliamentarians. By this, they encourage their individuals and supporters, and speak to their requests before parliament and government. Despite the fact that parties assume various crucial jobs and play out certain capacities in a majority rule society, however the choice and introduction of hopefuls in optional campaign is the most apparent limit. A few researchers host expounded on political gatherings and featured their importance in vote based system (Bryce, 1889; Schattschneider, 1942; Muller \& Strøm, 1999; Stokes, 1999; Strøm, Müller \& Bergman, 2006). Like other concepts in social sciences in general and political science in special, there is lack of consensus among scholars about the description of political development. For instance Huntington (1968) mentioned the level of political stability in a country as an indicator of its degree of political development, but later Huntington and Nelson (1976) pointed out that political participation is an important element of this process. Differences can also be found in terms of studying political development, for instance Almond and Coleman (1960) employed structural functionalism approach. Binder (1961) thinks, country's development lays in its capability to resolve certain crises of development such as penetration, participation, legitimacy, and so on.

\section{STATEMENT OF THE PROBLEM}

To measure and identify the role of political parties in the political progress of Pakistan is conducted. Pakistan is a democratic Republic Country and it rules by the political parties. The role of political parties is essential to the political progress in Pakistan.

\section{OBJECTIVES OF THE RESEARCH}

1. To identify the work of political groups in improvement of Pakistan

2. To discover the influence of political parties in political intensification of Pakistan

3. To examine the maturity of political parties to promote political system in the country.

Following research questions are formulated in order to ascertain the role of political parties in political development of Pakistan:

RQ1: What role political parties play for the improvement in Pakistani politics?

RQ2: How political parties influence political progress in Pakistan?

RQ3: How can political parties make sure to boost up political maturity?

\section{LITERATURE REVIEW}

An examination of the writing of this developmental segment of the recently conceived locale of political advancement demonstrates that as a base three crucial resources of political improvement investigation subsisted. Huntington and Dominguez (1975) have arranged them as:

i.System Function Approach. ii.Social Process Approach. 
iii.Comparative History Approach.

The System Function Approach mixed the elements of framework idea and development functionalism approach. It was determined and firmly propelled by crafted by a humanist Parsons (1971). The scientists are utilizing this methodology of their works include Easten (1953), Riggs (1964), Apter (1971), Levy (1966) and Almond (1970).

The societal improvement procedure endeavoured to relate political activities and course of development to social strategies together with industrialization, urbanization and creating media usage through close quantitative examinations of different social requests. It could be settled inside made by Lerner (1958), Deutsch (1961) and Needler (1968).

The relative history approach speaks to a blend of a more noteworthy traditional strategy with centred endeavours at orderly and legitimate exactitude. It can be chosen underway of Cyril (1966), Moore (1966) and Pye (1966).

The subsequent sentiment of "Political headway as the Politics standard of mechanical Societies" is also excitedly joined to budgetary issues. It includes the political endeavours of authoritatively industrialized and unmistakably common economies. In this mindset the politically made business social requests have set unequivocal gauges of political tradition and execution. Those standards depict the situating for political improvement like an adjustment for all the unmistakable social requests to look for after. Rostow (1960) has focussed the relationship among the headway and degrees of financial impact and the styles of political improvement.

The perspective on 'Political advancement as Political Modernisation' is essentially the augmentation of the previous systems. Business country lay the style and set the examples inside the periods of monetary and social ways of life. In this way, numerous individuals envision the indistinguishable to be applicable inside the political territory too. Social relativists like Lipset (1959), Coleman (1960), and Deutsch (1961), yet mission the legitimacy of distinguishing the business encounters as the bleeding edge and normal models for every one of the social orders.

\section{RESEARCH METHODOLOGY}

Survey questionnaire method was adopted to examine the position of political parties in political progress of Pakistan. Survey was conducted among the students and faculty members of political science departments of different colleges of Hyderabad city in order to collect reliable data. Data were collected by using 5 point Likert Scale comprising ten questions previously used by Pye (1966) with some modifications.

In survey, questions were asked about the perceived role and functions of political parties, concept of political development and the role of political parties in political development. While administering questionnaire, scholar was present to elaborate the context of questions and seek better understanding of the opinions of respondents.

\section{POPULATION AND SAMPLE}

The Population of this research consisted of teaching faculty (Professors, Associate Professors, Assistant Professors and Lecturers of Political Departments) of public sector colleges situated in Hyderabad city. 150 questionnaires were distributed in-person. 120 questionnaires were completed and returned the return rate of completed questionnaires is 
$80 \%$ of distributed questionnaires. Data were collected through random sampling method.

\section{DATA ANALYSIS}

Data received from the respondents through survey questionnaire were analyzed by using a Statistical Package for Social Sciences (SPSS) 22 version.

The statistical measurement tools used in this research comprised of descriptive statistics.

\section{RESULTS AND DISCUSSION}

An examination of table 1 reveals that majority of the respondents more than $56 \%$ are agreed with the question regarding the political parties are serving as a link between state and society while $40 \%$ of the respondents are shown their disagreement.

\section{Table 1 Political Parties Serve as a Link between State and Society (Public).}

\begin{tabular}{|l|r|r|r|r|}
\hline & Frequency & Percent & Valid Percent & Cumulative Percent \\
\hline Valid Strongly Disagree & 16 & 13.3 & 13.3 & 13.3 \\
Disagree & 24 & 20.0 & 20.0 & 33.3 \\
Neutral & 12 & 10.0 & 10.0 & 43.3 \\
Agree & 48 & 40.0 & 40.0 & 83.3 \\
Strongly Agree & 20 & 16.7 & 16.7 & 100.0 \\
Total & 120 & 100.0 & 100.0 & \\
\hline
\end{tabular}

In response to the question Political Development as a Pattern of Change in the State Structure and Society again majority of the respondents i.e. more than $63 \%$ are agreed whereas less than $17 \%$ are disagreed as shown in following table 2

Table 2 Political Development as a Pattern of Change in the State Structure and Society.

\begin{tabular}{|l|r|r|r|r|}
\hline & Frequency & Percent & Valid Percent & Cumulative Percent \\
\hline Valid Strongly Disagree & 12 & 10.0 & 10.0 & 10.0 \\
Disagree & 8 & 6.7 & 6.7 & 16.7 \\
Neutral & 24 & 20.0 & 20.0 & 36.7 \\
Agree & 48 & 40.0 & 40.0 & 76.7 \\
Strongly Agree & 28 & 23.3 & 23.3 & 100.0 \\
Total & 120 & 100.0 & 100.0 & \\
\hline
\end{tabular}

In examination of table 3 it is clearly indicated that more than $63 \%$ of the respondents are agreed and less than $14 \%$ are disagreed with the question relating to the political development as the capacity of political parties to harmonize Growth of Different Sectors. 
Table 3 Political Development as the Capability of Political Parties to Synchronize Growth of Different Sectors

\begin{tabular}{|l|r|r|r|r|}
\hline & Frequency & Percent & Valid Percent & Cumulative Percent \\
\hline Valid Strongly Disagree & 8 & 6.7 & 6.7 & 6.7 \\
Disagree & 8 & 6.7 & 6.7 & 13.3 \\
Neutral & 28 & 23.3 & 23.3 & 36.7 \\
Agree & 60 & 50.0 & 50.0 & 86.7 \\
Strongly Agree & 16 & 13.3 & 13.3 & 100.0 \\
Total & 120 & 100.0 & 100.0 & \\
\hline
\end{tabular}

In response of the question regarding to the primary focus of political parties is on urban rather than rural development, $56 \%$ of the respondents appeared to be agreed while $48 \%$ are disagreed as shown in the following table 4.

Table 4 The Primary Focus of Political Parties is on Urban rather than Rural Development.

\begin{tabular}{|l|r|r|r|r|}
\hline & Frequency & Percent & Valid Percent & Cumulative Percent \\
\hline Valid Strongly Disagree & 4 & 3.3 & 3.3 & 3.3 \\
Disagree & 44 & 36.7 & 36.7 & 40.0 \\
Neutral & 16 & 13.3 & 13.3 & 53.3 \\
Agree & 44 & 36.7 & 36.7 & 90.0 \\
Strongly Agree & 12 & 10.0 & 10.0 & 100.0 \\
Total & 120 & 100.0 & 100.0 & \\
\hline
\end{tabular}

An inspection of the following table 5 indicates that the $60 \%$ of the respondents are agreed whereas only $30 \%$ have shown disagreement.

Table 5 Trust Deficit in Political Parties Leads towards the Pursuance of Individual Interests.

\begin{tabular}{|l|r|r|r|r|}
\hline & Frequency & Percent & Valid Percent & Cumulative Percent \\
\hline Valid Strongly Disagree & 12 & 10.0 & 10.0 & 10.0 \\
Disagree & 24 & 20.0 & 20.0 & 30.0 \\
Neutral & 12 & 10.0 & 10.0 & 40.0 \\
Agree & 56 & 46.7 & 46.7 & 86.7 \\
Strongly Agree & 16 & 13.3 & 13.3 & 100.0 \\
Total & 120 & 100.0 & 100.0 & \\
\hline
\end{tabular}

While examining the following table 6 , it is indicated that more than $73 \%$ of the respondents are agreed whereas only more than $23 \%$ are disagreed. 
Table 6 The Prosperity of Society and Economy is Dependent on Stability of Political system.

\begin{tabular}{|l|r|r|r|r|}
\hline & Frequency & Percent & Valid Percent & Cumulative Percent \\
\hline Valid Strongly Disagree & 4 & 3.3 & 3.3 & 3.3 \\
Disagree & 24 & 20.0 & 20.0 & 23.3 \\
Neutral & 4 & 3.3 & 3.3 & 26.7 \\
Agree & 60 & 50.0 & 50.0 & 76.7 \\
Strongly Agree & 28 & 23.3 & 23.3 & 100.0 \\
Total & 120 & 100.0 & 100.0 & \\
\hline
\end{tabular}

An examination of table 7 it is reveals that $50 \%$ of the respondents are seems to be agreed with the political Development through Strengthening Representative Institutions while $40 \%$ of the respondents are disagreed.

Table 7 Political Development through Strengthening Representative Institutions.

\begin{tabular}{|c|c|c|c|c|c|}
\hline & \multirow{2}{*}{$\frac{\text { Frequency }}{20}$} & Percent & Valid Percent & Cumulative Percent \\
\hline & & & \multirow{6}{*}{$\begin{array}{r}16.7 \\
23.3 \\
10.0 \\
40.0 \\
10.0 \\
100.0\end{array}$} & \multirow{5}{*}{$\begin{array}{r}16.7 \\
23.3 \\
10.0 \\
40.0 \\
10.0\end{array}$} & \multirow{6}{*}{$\begin{array}{r}16.7 \\
40.0 \\
50.0 \\
90.0 \\
100.0\end{array}$} \\
\hline & $\begin{array}{ll}\text { Valid } & \text { Strongly Disagree } \\
& \text { Disagree }\end{array}$ & \multirow{4}{*}{$\begin{array}{l}20 \\
28 \\
12 \\
48 \\
12\end{array}$} & & & \\
\hline & & & & & \\
\hline & & & & & \\
\hline & $\begin{array}{l}\text { Disagree } \\
\text { Neutral } \\
\text { Agree } \\
\text { Strongly Agree }\end{array}$ & & & & \\
\hline & $\begin{array}{l}\text { Neutral } \\
\text { Agree } \\
\text { Strongly Agree } \\
\text { Total }\end{array}$ & 120 & & 100.0 & \\
\hline
\end{tabular}

In response of the question regarding political development through democracy within the party structure it appears that $60 \%$ of the respondents are agreed whereas less than $27 \%$ are disagreed.

Table 8 Political Development through Democracy within the Party Structure.

\begin{tabular}{|l|r|r|r|r|}
\hline & Frequency & Percent & Valid Percent & Cumulative Percent \\
\hline Valid Strongly Disagree & 24 & 20.0 & 20.0 & 20.0 \\
Disagree & 8 & 6.7 & 6.7 & 26.7 \\
Neutral & 16 & 13.3 & 13.3 & 40.0 \\
Agree & 32 & 26.7 & 26.7 & 66.7 \\
Strongly Agree & 40 & 33.3 & 33.3 & 100.0 \\
Total & 120 & 100.0 & 100.0 & \\
\hline
\end{tabular}

Table 9 indicates that $80 \%$ of the participants are agreed with the question relating to the political stability is directly proportional to political participation and less than $7 \%$ are disagreed.

$=$ International Research Journal of Education and Innovation $\overline{=}$ [97 ] = 
Table 9 The Political Stability is Directly Proportional to Political Participation.

\begin{tabular}{|l|r|r|r|r|}
\hline & Frequency & Percent & Valid Percent & Cumulative Percent \\
\hline Valid Strongly Disagree & 4 & 3.3 & 3.3 & 3.3 \\
Disagree & 4 & 3.3 & 3.3 & 6.7 \\
Neutral & 16 & 13.3 & 13.3 & 20.0 \\
Agree & 48 & 40.0 & 40.0 & 60.0 \\
Strongly Agree & 48 & 40.0 & 40.0 & 100.0 \\
Total & 120 & 100.0 & 100.0 & \\
\hline
\end{tabular}

Following table 10 of the survey indicates that more than $66 \%$ of the respondents are agreed about the significant role of political parties in political development while less than $24 \%$ of participants are disagreed.

Table 10 Political Participation is Vital for Political Parties and Political Development.

\begin{tabular}{|ll|r|r|r|r|}
\hline & Frequency & Percent & Valid Percent & Cumulative Percent \\
\hline Valid Strongly Disagree & 12 & 10.0 & 10.0 & 10.0 \\
Disagree & 16 & 13.3 & 13.3 & 23.3 \\
Neutral & 12 & 10.0 & 10.0 & 33.3 \\
Agree & 60 & 50.0 & 50.0 & 83.3 \\
Strongly Agree & 20 & 16.7 & 16.7 & 100.0 \\
Total & 120 & 100.0 & 100.0 & \\
\hline
\end{tabular}

\section{CONCLUSION}

The main purpose of this study is to explore the role of political parties in political development of Pakistan. The period for the study is limited only for the tenure of PPP from 2008- 2013 and the period of PML (N) from 2013-2018. Before 2008 political parties were dominated by military dictator and after the assassination of Shaheed Muhtarma Benazir Bhutto in 2007 PPP came into power and completed its tenure first time in the history of Pakistan. In 2013 PML (N) came into power and this was the smooth transfer of powers from one Democratic Party to another. The results of this study reveal that there is vital role of political parties in the development of democracy in the country. This study further reveals that political parties should play a positive role for the political stability because political parties are the representatives of the society and they are well aware about the problems of the public. For stable political system, Pakistan needs considerable improvement, capacity building and institutionalization. The productive role of political parties not only improves the intensity of political growth in the country but also encourage wisdom of ownership and belonging among the masses. 


\section{REFERENCES}

1. Akhtar, N. (2011). Role of political parties in the democratic system of Pakistan. Karachi: Oxford University Press.

2. Almond, G. A., \& Coleman, J. S. (1960). The politics of developing areas. Princeton: Princeton University Press.

3. Almomnd, Gabrial (1970). Political Development. Boston: Little Brown.

4. Apter, David (1971), Choice and the Politics of Education. New Haven: Yale University Press.

5. Binder, L. (1961). Religion and politics in Pakistan. Los Angeles: University of California Press.

6. Black, Cyril E. (1966). The Dynamics of Modernization. New York: Harper and Row.

7. Bryce, J. (1889). The American commonwealth (2nd ed.). London: Macmillan and Co.

8. Cohen, S. P. (2004). The idea of Pakistan. Washington, D.C., USA: Brookings Institution Press.

9. Coleman, James S. (1960). "The political systems of the developing areas". In Gabrial A. Almond and James S. Coleman. Eds. The Politics of Developing Areas. Princeton: Princeton University Press.

10. Deutsch, K W. (1961). Social mobilization and political development. The American Political Science Review, 55(3), 493-514.

11. Easten, David (1953). The Political System. New York: Knopf.

12. Hah, C., \& Schneider, J. (1968). A critique of current studies of political development and modernization. Social Research, 35(1), 130-158.

13. Huntington, S. P. (1968). Political order in changing societies. New Haven: Yale University.

14. Huntington, S. P., \& Nelson, J. M. (1976). No easy choice: Political participation in developing countries. Cambridge: Harvard University Press.

15. Huntington, Samuel P. and Jorge I. Dominguez (1975). "Political development". In Greenstein and Polsby (eds.). Handbook of Political Science. V. 3. California: AddisonWesley Publishing Company.

16. Hussain, M., \& Kokab, R. (2013). Institutional influence in Pakistan: Bureaucracy, cabinet and parliament. Asian Social Science, 9(7), 173-178.

17. La Palombara, J. (1963). Bureaucracy and political development. Princeton: Princeton University Press.

18. Lerner, Daniel (1958). The Passing of Traditional Societies. New York: Free Press.

19. Levy, Marion J. Jr. (1966). Modernization and the Structure of Societies. Princeton: Princeton University Press.

20. Lipset, Seymour Martin (1959). "Some social requisites of democracy: economic development and political legitimacy". American Political Science Review. LIII. No. 1.

21. Moore, B. (1966). Social origins of dictatorship and democracy: Lord and peasant in the making of the modern world. Boston: Beacon Press.

22. Müller, W. C., \& Strøm, K. (1999). Policy, office, or votes?: How political parties in Western Europe make hard decisions. Cambridge: Cambridge University Press.

23. Needler, Martin C. (1968). Political Development in Latin America: Instability, Violence and Evolutionary Change. New York: Random House.

24. Packenham, R. A. (1964). Approaches to the study of political development. World

$=$ International Research Journal of Education and Innovation 
Politics, 17(1), 108-120.

25. Parsons, Talcot (1971). The System of Modern Societies. Englewood Cliffs: Prentice Hall Inc.

26. Riggs, Fred (1964). Administration in Developing Prismatic Society. Boston: Houghton Mifflin.

27. Pye, L. W. (1963). Communications and political development. Princeton: Princeton University Press.

28. Pye, L.W. (1966). Aspects of political development. Boston: Little Brown.

29. Pye, L. W., \& Verba, S. (2015). Political culture and political development. Princeton: Princeton University Press.

30. Rostow, W. W. (1960). The stages of Economic Growth: A Non-Communist Manifesto. London: Cambridge University Press.

31. Rudebeck, L. (1970). Towards a coherent and relevant theoretical formulation of the concept. Scandinavian Political Studies, 5(A5), 21-63.

32. Schattschneider, E. E. (1942). Party government. New York: Holt, Rinehart and Winston.

33. Stoke, S. C. (1999). Political parties and democracy. Chicago: University of Chicago.

34. Strom, K., Müller, W. C., \& Bergman, T. (2006). Delegation and accountability in parliamentary democracies. New York: Oxford University Press.

35. Weiner, M. (1962). The Politics of scarcity: Public pressure and political response in India. Chicago: Chicago University Press. 